\title{
MEMAHAMI KODE PHONETIC ALPHABET PADA KOMUNIKASI RADIO MARINE
}

\author{
Winny Rizal Pranata \\ (pranata_rizal@gmail.com) \\ (Alumni Jurusan Ilmu Komunikasi Universitas Semarang)
}

\begin{abstract}
This study purpose to understand and describe in detail and in-dept understanding of the meaning and the use of phonetic alphabet in radio marine communication. Theory used in this study is syimbolic interaksionisme that states when a movement in sociology focused to way people shape the meaning and structure of the community through conversations. The research method used is descriptive qualitative with interpretive perspective.

This research was conducted PT. Pelabuhan Indonesia Scouting III Tanjung Emas Semarang with three (3) sample person as radio marine operator.In concluded for this study has answered phonetic alphabet code is a symbol that used to interaction tool for equalized and straighten meaning when there is misunderstanding in the delivery and reception of informationbetween both radio operator in radio marine communication especially PT. Pelabuhan Indonesia III Tanjung Emas Semarang to understand the meaning from the contents of the message to be effective communication.
\end{abstract}

Kata Kunci: Komunikasi, Radio Marine, Kode Phonetic Alphabet

\section{PENDAHULUAN}

Dalam dunia komunikasi khususnya saat ini dimana komunikasi dilakukan dengan tujuan mendapatkan informasi yang lebih cepat dan tidak harus menunggu lama. Salah satunya adalah komunikasi radio (Syamsu, 2004: 7). Alat komunikasi yang populer serta merupakan media massa paling luas di dunia. Hampir terdapat 35.000 stasiun radio di seluruh dunia di darat maupun lautan. Komunikasi ditransmisikan secara serempak melalui gelombang radio di udara yang jangkauannya melebihi surat kabar, media cetak maupun televisi.

Namun dalam penelitian ini bukanlah radio dalam bidang jurnalisme yang akan dipaparkan melainkan suatu jenis radio yang digunakan sebagai alat komunikasi di wilayah laut. Dengan berbasis Variable High Frekuensi (VHF), radio ini memungkinkan kita dapat mengirimkan pesan radio jarak jauh, tentunya dengan mengacu pada ciri khas utama radio adalah auditif, yakni dikonsumsi telinga atau pendengaran. Apa yang dilakukan radio adalah memperdengarkan suara manusia untuk mengutarakan sesuatu, sesuai dengan yang dibutuhkan pengguna komunikasi pada wilayah laut khususnya.

Radio VHF digunakan dan terpasang pada semua kapal-kapal besar dan berlayar di laut. Secara fungsional yang utama, radio ini digunakan untuk berbagai keperluan,seperti layanan penyelamatan, dan berkomunikasi dengan master pelabuhan, kapal lain saat berpapasan, kunci, jembatan dan marina. Radio ini beroperasi di rentang frekuensi VHF, antara 156-174. Satu set VHF Marine terdiri dari pemancar dan penerima serta hanya beroperasi 
pada standar, frekuensi internasional dikenal sebagai saluran.

Dengan melihat fungsi serta ciri khas dan tipikal dari jenis radio yang telah dipaparkan di atas, maka dikenallah istilah radio marine yang arti dan fungsi utamanya adalah sebagai komunikasi utama dalam wilayah kelautan yang digunakan sebagai alat penyambung antara kapal dengan pihak-pihak lain seperti penjaga pantai, master harbour (disebut juga syahbandar) dalam proses penyelamatan olah gerak di wilayah pelabuhan dan macam fungsi yang lain.

Orang yang menjalankan tugas atau berprofesi mengoperatori alat radio marine di laut maupun stasiun radio pelabuhan disebut sebagai markonis ataupun radio operator. Tugas dari markonis pun secara keseluruhan sama seperti fungsi radio marine seperti yang dijelaskan diatas. Seorang radio operator di kapal bertugas sebagai pengirim maupun penerima berita/informasi dari pihak lain seperti stasiun radio pantai atau pelabuhan, kapal lain maupun pihak yang berkepentingan pada kapal tersebut dan akan segala informasi itu lah yang akan disampaikan kepada nahkoda sebagai pemimpin di kapal. Sedangkan untuk radio operator marine yang bertugas di darat seperti yang ada di stasiun radio pantai atau pelabuhan.

Permasalahan yang melatar belakangi komunikasi tidak dapat berjalan efektif ini diakibatkan karena adanya gangguan berupa cuaca buruk, informasi yang disampaikan oleh komunikator, belum tentu sama maksudnya saat diterima komunikan. Hal itu dikarenakan suara yang diterima tidak maksimal, entah karena terputus-putus ataupun suara yang diterima tidak jelas. Apalagi saat terjadi komunikasi antara dua pihak yang berbeda bahasa, pasti akan banyak terjadi kesalahpahaman lagi. Memang bahasa Inggris adalah bahasa baku dan universal dalam komunikasi pelayaran, namun setiap orang dengan bahasa negara yang berbeda pasti mempunyai dialek yang berbeda pula.Perbedaan pengucapan dalam komunikasi ini pun juga menjadi permasalahan yang fatal. Penyampaian sebuah kata dan kalimat bisa diterima dengan maksud yang berbeda karena kesalah pahaman bahasa dan pengucapan yang berbeda antara tiap individu. Hal itu lebih buruk apabila ditambah lagi dengan individu yang berbeda negara dan kesulitan dalam berbahasa Inggris yang tentunya akan menyebabkan perbedaan pemaknaan/interpretasi suatu kata dalam komunikasi dan pesan tidak tersampaikan secara efektif.

Terkadang ada beberapa kata spesifik atau unik yang perlu kita sampaikan kepada pihak ketiga atau teman bicara. Karena jumlah kata yang relatif panjang dan antar beberapa huruf memiliki kesamaan dalam pengucaman membuat lawan bicara akan kebingungan untuk menentukan apa sebenarnya yang diucapkan oleh komunikator.

Untuk mengatasi permasalahan tersebut, dalam komunikasi radio pelayaran maupun lainnya terdapat suatu bahasa isyarat ataupun simbol untuk mengantisipasi dan menangani kesalahpahaman dalam berkomunikasi. Simbol atau kode yang berupa susunan huruf abjad sesuai standar internasional pelayaran itu disebut dengan kode phonetic alphabet. Kode tersebut dimanfaatkan untuk mengulang atau mengeja huruf dan kata yang tidak tersampaiakan atau diterima dengan baik dalam suatu percakapan melalui komunikasio radio marine oleh soaran operator radio demi menciptakan komunikasi yang efektif. Hal tersebut 
yang menjadi dasar penulis mengadakan penelitian ini.

\section{Tinjauan Pustaka \\ 1.1 Teori Komunikasi}

Dalam suatu penelitian, teori mendapat kedudukan yang sangat penting dengan berbagai fungsi utamanya. Kedudukan teori khususnya dalam suatu kegiatan penelitian seperti yang diungkapkan oleh Kaplan dan Manners, sehingga hampir tidak ada sesuatu yang tidak berangkat dari teori dengan satu atau beberapa fungsinya. Kemudian sebuah teori diarahkan untuk menjawab pertanyaan mengapa (bagaimana) timbul regularitas alam, dengan demikian teori harus memuat pertanyaan tentang mekanisme tertentu, serta hubungan antar variabel dalam fenomena yang diselidiki (Kaplan dan Manners, 2002: 123). Dalam penelitian kualitatif teori yang dikembangkan dimulai dilapangan dimulai di lapangan studi dari data yang terpisahpisah dan atas bukti-bukti yang terkumpul serta saling berkaitan. Penekanannya pada proses analisis induktif, sehingga penelitian yang demikian juga disebut sebagai empirico inductive researh (Kaplan dan Manners dalam Sutopo, 2002: 39).

\subsection{Komunikasi Antar Budaya Efektif}

Masalah utama dalam komunikasi antarbudaya adalah kesalahan dalam persepsi sosial yang disebabkan oleh perbedaan-perbedaan budaya yang mempengaruhi proses persepsi (Mulyana \& Rahmat, 2001: 34). Dalam proses komunikasi antar budaya terjadi sebuah hambatan dan masalah yang sama seperti yang dihadapi oleh bentuk-bentuk komunikasi yang lain. Dalam menciptakan sebuah keefektifan komunikasi antarbudaya, komunikasi akan lengkap bila penerima pesan yang dimaksud mempersepsi atau menyerap perilaku yang disandi, memberi makna kepadanya dan terpengaruh olehnya. Dalam transaksi komunikasi harus dimaksukkann semua stimuli sadar-tak sadar, sengaja-tak sengaja, verbal, non verbal yang kontekstual yang berperan sebagai isyarat-isyarat kepada sumber dan penerima tentang kualitas dan kredibilitas pesan. Dalam proses interaksi antarbudaya sama halnya dengan harus memperhatikan delapan unsur komunikasi, kedelapan unsur tersebut yaitu, sumber (source), penyandian (ecoding), pesan (message), saluran (channel), penerima (receiver), penyandian balik (decoding), respon penerima (receiver response) dan yang terakhir umpan balik (feedback) Dalam pembahasan tentang komunikasi antar budaya, tidaklah lengkap apabila tidak mencantumkan konsep Dialektologi dan Sosiolinguistik. Menurut Pateda, Dialektologi adalah teori yang mempelajari serta membandingkan bahasa-bahasa yang masih serumpun untuk mencari titik persamaan dan titik perbedaannya (Pateda, 1988: 51). Dalam Kamus Lingustik dikatakan bahwa sosiolinguistik adalah cabang linguistik yang mempelajari hubungan dan saling pengaruh antara perilaku bahasa dengan perilaku sosial (Kridalaksana, 1993: 181).

\subsection{Komunikasi Antar Pribadi}

Joseph A. Devito dalam bukunya "The Interpersonal Communication Book" mendefinisikan komunikasi antarpribadi sebagai: "Proses pengiriman dan penerimaan pesanpesan antara dua orang atau di antara sekelompok kecil orang-orang, dengan beberapa efek dan beberapa umpan balik seketika". Berdasarkan definisi itu, komunikasi antarpribadi dapat berlangsung antara dua orang yang memang sedang berdua-dua atau antara 
dua orang dalam suatau pertemuan. Pentingnya situasi komunikasi antarpribadi ialah karena prosesnya memungkinkan berlangsung secara dialogis, di mana selalu lebih baik daripada secara monologis. Monolog menunujkkan suatu bentuk komunikasi di mana seorang berbicara, yang lain mendengarkan, jadi tidak terdapat interaksi.

Sebagai suatu proses, komunikasi antarpribadi merupakan rangkaian tindakan, kejadian dan kegiatan yang terjadi secara terus menerus atau bisa dibilang merupakan suatu yang dinamis (Marhaeni Fajar, 2009: 81). Bila diartikan lebih luas, dalam komunikasi antar pribadi, seorang komunikastor bisa sekaligus menjadi komunikan yang dalam prosesnya lagi berlangsung secara terus menerus dan tidak tahu kapan akan berakhir.

Tahapan-tahapan dalam komunikasi antarpribadi adalah (1) Kontak (first impression), Perkenalan, (3) Pertemanan, Decline (puncak), (5) Perpecahan (Marhaeni Fajar, 2009: 86). Komunikasi antarpribadi sebagai suatu bentuk perilaku, dapat berubah dan sangat tidak efektif. Pada suatu saat komunikasi bisa lebih buruk dan pada saat lain bisa lebih baik (Marhaeni Fajar, 2009: 84). Tetapi dibalik itu semua terdapat suatu keunikan dalam proses komunikasinya yang dilakukan secara fleksibel.

\subsection{Interaksionisme Simbolik}

Seperti yang sampaikan oleh Basrowi dan Sukidin, interaksionisme simbolik merupakan suatu hubungan yang terjadi secara alami antara manusia dalam masyarakat dan hubungan masyarakat dengan individu. Interaksi yang terjadi antar individu berkembang melalui simbol-simbol yang mereka ciptakan. Realitas sosial merupakan rangkaian peristiwa yang terjadi pada beberapa individu dalam masyarakat. Interaksi yang dilakukan antar individu itu berlangsung secara sadar dan berkaitan dengan gerak tubuh, vokal, suara, dan ekspresi tubuh, yang kesemuanya itu memopunyai maksud dan disebut dengan simbol (Basrowi \& Sukidin dalam Engkus Suwarno, 2008: 22).

Seperti yang disampaikan juga oleh Littlejhon, interaksionisme simbolis, sebuah pergerakan dalam sosiologi, berfokus pada cara-cara manusia membentuk makna dan suasana dalam masyarakat melalui percakapan (Littlejhon, 2009: 231). Dijelaskan pula bahwasanya pelaku memilih, memeriksa, menahan, menyusun kembali, dan mengubah makna untuk mengetahui situasi di mana ia ditempatkan dan arah dari tindakan-tindakannya (Littlejhon, 2009: 233). Interaksionisme simbolis sebagai sebuah gerakan, ada untuk meneliti cara-cara manusia berkomunikasi, memusat, atau dapat membagi makna (Littlejhon, 2009: 236).

\subsection{Pemanfaatan Kode Phonetic Alphabet \\ Dalam ranah komunikasi} pelayaran atau radio marine, istilah phonetic alphabet sudah tidak asing lagi. Hal itu dikarenakan manfaat istilah itu yang amat sangat berguna dalam penggunaannya pada bidang pelayaran. Seperti yang disampaikan tim penyusun semboyan untu mualim pelayaran besar, kode phonetic alphabet merupakan sebuah bahasa baku yang menggunakan huruf abjad atau alfabet sebagai penyampaian bahasa yang agaknya susah dimengerti serta jauh lebih efektif saat disampaiakn komunikator kepada komunikan. Kode phonetic alphabet 
merupakan suatu istilah kode isyarat baku yang menggunakan huruf abjad atau alfabet sebagai penyampaian bahasa yang agaknya susah dimengerti serta lebih efektif saat disampaikan komunikator kepada komunikan (Semboyan Untuk Mualim Pelayaran Besar, 1979: 39).

Pada saat terjadi suatu komunikasi, seringkali terdapat kesalahpahaman dalam penyampaian dan penerimaan pesan. Hal itu bisa terjadi miss comunication antara komunikator dan komunikan. Entah diakibatkan oleh berbagai kendala seperti bahasa dan cara pengucapan yang berbeda, pesan yang terputus karena penerimaan radio yang buruk. Maka dari itu diperlukan suatu cara, yaitu menggunakan phonetic alphabet pada proses komunikasi pelayaran sebagai kode untuk membantu penyampaian pesan yang terputus agar terjadi komunikasi yang efektif. Berikut adalah daftar phonetic alphabet beserta pelafalannya Berikut adalah kode phonetic alphabet yang digunakan: A (Alpha), B (Bravo), $C$ (Charlie), D (Delta), E (Echo), F (Foxtrot), $G$ (Golf), $H$ (Hotel), I (India), $J$ (Juliet), K (Kilo), L (Lima), $M$ (Mike), $N$ (November), $O$ (Oscar), $P$ (Papa), $Q$ (Quebec), $R$ (Romeo), $S$ (Sierra), $T$ (Tango), $U$ (Uniform), $V$ (Victor), $W$ (Whiskey), $X$ (X-Ray), $Y$ (Yankee), Z (Zulu).

\subsection{Komunikasi Efektif}

Marhaeni Fajar menyampaikan, komunikasi adalah suatu kegiatan yang dilakukan secara sadar, disengaja serta sesuai dengan tujuan atau keinginan dari pelakunya (Marhaeni Fajar, 2009: 33). Kegiatan komunikasi pada prinsipnya adalah aktivitas pertukaran ide atau gagasan. Secara sederhana, kegiatan komunikasi dipahami sebagai kegiatan penyampaian dan penerimaan pesan atau ide dari satu pihak ke pihak lain, dengan tujuan untuk mencapai kesamaan pandangan atas ide yang dipertukarkan tersebut.

Marhaeni Fajar pun menyimpulkan bahwa komunikasi yang efektif adalah komunikasi yang akan memberikan umpan balik (feed back) terhadap pesan yang disampaikan oleh komunikator. Umpan balik memainkan peranan yang amat penting dalam komunikasi sebab ia menentukan berlanjutnya komunikasi atau berhentinya komunikasi yang di utarakan oleh komunikator, oleh karena itu, umpan balik bisa bersifat positif atau negatif. Setelah itu akan menimbulkan impact yaitu tanggapan, seperangkat reaksi pada komunikan setelah menerima pesan dari komunikator. Tanggapan komunikan apabila tersampaikan atau disampaikan kepada komunikator terhadap isi pesan, yang dapat menimbulkan reaksi dari kedua belah pihak (Marhaeni Fajar, 2009: 59). Maksud dari komunikasi efektif sama dengan apa yang telah diterangkan di atas, yakni tersampaikannya pesan dari komunikator sama dengan apa yang diterima komunikan dengan jelas tanpa ada pesan yang terputus.

\section{Metode Penelitian}

\subsection{Bentuk dan Strategi Penelitian}

Berdasar masalah yang diajukan dalam penelitian yang telah dilakukan ini lebih menekankan pada proses, maka jenis penelitian dengan strateginya yang terbaik adalah penelitian kualitatif deskriptif. Dengan penelitian ini diharapkan mampu menangkap berbagai informasi kualitatif dengan deskriptif yang teliti, penuh nuansa natural (Lincoln dan Guba, 1985).

Strategi yang digunakan adalah studi kasus, dan karena lokasinya satu kota (Semarang) dan hanya 
menyangkut informan yang berada di Kantor Kepanduan Semarang PT. Pelabuhan Indonesia III Tanjung Emas, serta yang diamati hanyalah pemanfaatan phonetic alphabet oleh radio operator kepanduan, pandu bandar dan markonis kapal yang tengah sandar di pelabuhan, maka dinakanlah strategi studi kasus tunggal terpancang (Sutopo, 2002). Disebut studi kasus tunggal terpancang karena permasalahan dan fokus penelitiannya sudah ditentukan lebih dahulu sebelum peneliti terjun menggali permasalahan di lapangan.

\subsection{Data dan Sumber Data}

a. Data primer, merupakan data utama yang diperoleh langsung dari key informant yang sekaligus merupakan subyek penelitian ini melalui wawancara mendalam (indepth interview) dengan menggunakan interview guide sebagai pedoman wawancara. Key informant dalam penelitian adalah Radio Operator Kepanduan Semarang yaitu Abdusomad Buchori, Pandu Bandar di Kepanduan Semarang yaitu Panca Pemilu Andriyono serta seorang Mualim 2/ Markonis (radio operator) kapal container MV. URU BHUM yaitu Atchinyang harus memenuhi karakter sebagai berikut:

- Seorang radio operator pelabuhan ataupun markonis kapal harus memiliki sertifikat/ijazah radio. Dalam hal ini, key informant radio operator dari Kepanduan Semarang maupun mualim 2/ markonis dari MV. URU BHUM memiliki ijazah GMDSS (Global Maritime Distress and Safety System).

- Radio operator yang telah memiliki ijazah radio pasti telah mendapatkan pendidikan tentang bab phonetic alphabet sebagai bekal untuk penguasaan serta saat terjun ke lapangan.
- Radio operator harus sudah mempunyai masa bertugas minimal 1 tahun. Hal itu mempengaruhi sumber data dan informasi yang bisa diberikan, karena semakin lama bertugas semakin banyak juga pengalaman dan materi yang disampaikan. Apalagi bila menyangkut tentang hambatan (komunikasi) dengan radio marine, dipastikan hal tersebut telah banyak dialami olehnya.

- Pandu Bandar sebagai perwira pandu yang bertugas suntuk melakukan pemanduan kapal di wilayah alur pelabuhan dan yang tentunya telah mempunyai spesifikasi yang dimiliki seorang radio operator karena dalam pelaksaan pekerjaannya seorang pandu juga melakukan bentuk komunikasi radio marine.

b. Data sekunder, merupakan data terkumpul dari literatur terkait dan sumber-sumber lain seperti artikel media cetak/situs internet yang memiliki relevansi dengan masalah yang diteliti.

\subsection{Teknik Sampling}

Penelitian ini menggunakan teknik cuplikan yang bersifat selektif, dengan menggunakan pertimbangan berdasarkan konsep teoritis yang digunakan, keinginan pribadi peneliti, karakter empirisnya, dan lain-lainnya. Oleh karena itu cuplikan yang digunakan dalam penelitian ini bersifat puposive sampling atau lebih disebut sebagai cuplikan dengan "criterionbased selection" (Goetz \& LeCompte, dalam Sutopo, 2002).

\subsection{Teknik Pengumpulan Data}

Data penelitian ini diperoleh dari kegiatan wawancara mendalam (indepth-interview) dengan subyek penelitian ini yang berusaha melakukan interpretasi atau memberikan makna terhadap pengalamannya dalam melakukan komunikasi radiomarine 
yang menggunakan phonetic alphabet. Karena penelitian ini bersifat kualitatif, maka instrumen untuk melakukan wawancara adalah penelitian sendiri dengan menggunakan pedoman wawancara (interview guide) yang tidak terstruktur dan bersifat openended. Pertanyaan-pertanyaan yang sifatnya open-ended tersebut merupakan sarana yang paling efektif untuk memahami otentisitas pengalaman individu atau personal. Hasil wawancara ini ditulis sebagai catatan dan sebagian dengan audiotape yang sarananya menggunakan handphone sebagai alat perekam.

Disamping wawancara juga dilakukan studi kepustakaan yaitu pengumpulan data dan informasi yang berasal dari sumber tertulis seperti surat kabar, buku-buku, majalah, internet, dan sebagainya (Sutopo, 2002: $35)$.

\subsection{Validitas Data}

Semua alat ukur dikatakan valid apabilaalat ukur tersebut mengukur apa yang ingin diukur (Singarimbun, 1989: 124). Memiliki kesamaan dan ketepatan dalam pengukuran atau mampu menunjukan dengan tepat ukran besar kecilnya gejala yang akan diukur. Setelah mendapatkan data yang cukup lengkap dan peneliti mulai menyusun laporan, maka unit-unit laporan yang telah disusun dikomunikasikan dengan key informan. Hal ini perlu dilakukan untuk mengetahui apakah laporan yang ditulis tersebut merupakan deskripsiatau sajian yang disetujui mereka, sehingga ada kesamaan pemahaman dari peneliti dan informan.

\subsection{Analisis Data}

Analisis data adalah upaya untuk mencari dan menata secara sistematis catatan wawancara, telaah kepustakaan dan lainnya untuk meningkatkan pemahaman peneliti tentang kasus yang diteliti dan menyajikannya sebagai temuan bagi orang lain. Data tersebut diolah dan dianalisa kembali maksudnya agar menjadi ringkas, yang meliputi proses mulai dari menuliskan kembali hasil wawancara atau rekaman yang dilakukan dilapangan yang kemudian dilanjutkan dengan kegiatan mengedit, mengklasifikasikan, mereduksi serta menyajikannya. Sementara itu untuk meningkatkan pemahaman tersebut, analisis perlu dilanjutkan dengan upaya mencari makna (meaning).

\section{HASIL DAN PEMBAHASAN}

Sebagai petugas penyampai dan penerima informasi mengenai pergerakan kapal serta mengatur olah gerak kapal di wilayah pelabuhan, radio operator pada Kepanduan PT. Pelabuhan Indonesia III Tanjung Emas Semarang mempunyai peran vital sebagai seorang pelaku komunkasi di dalamnya. Ketepatan informasi serta kelancaran dalam proses komunikasi menjadi modal utama dalam proses pekerjaan pemanduan kapal yang dilakukan secara bekerja sama dengan pihak kapal serta pandu bandar.

Dalam proses komunikasi tersebut, acapkali muncul berbagai gangguan (noise) yang menghambat penyampaian dan penerimaan informasi antara komunikator dan komunikan. Berbagai gangguan yang muncul dalam proses komunikasi harus diminimalisir agar penyampaian serta penerimaan pesan dapat berjalan dengan baik sehingga terwujud komunikasi yang efektif. Hambatan yang muncul dapat menimbulkan kesalahpahaman maksud atas pesan 
yang disampaikan maupun diterima. Kesalah pahaman itu merupakan sebuah tanggapan terhadap isi pesan yang tidak dapat diterima dengan jelas. Tanggapan komunikan apabila tersampaikan atau disampaikan kepada komunikator terhadap isi pesan, yang dapat menimbulkan reaksi dari kedua belah pihak" (Marhaeni Fajar, 2009: 59).

Gangguan yang sering dialami oleh radio operator pada Kepanduan PT. Pelabuhan Indonesia III Tanjung Emas Semarang diakibatkan beberapa faktor diantaranya disebabkan oleh cuaca buruk yang mengakibatkan sinyal radio tidak dapat diterima dengan baik. Perbedaan budaya antara kedua belah pihak komunikasi yang mengakibatkan perbedaan pengucapan huruf juga dapat menimbulkan kesalahpahaman makna. Masalah utama dalam komunikasi yang melibatkan perbedaan budaya adalah kesalahan dalam persepsi sosial yang disebabkan oleh perbedaan-perbedaan budaya yang mempengaruhi proses persepsi. (Mulyana \& Rahmat, 2001: 34). Dalam menciptakan sebuah keefektifan komunikasi antarbudaya, komunikasi akan lengkap bila penerima pesan yang dimaksud mempersepsi atau menyerap perilaku yang disandi, memberi makna kepadanya dan terpengaruh olehnya.

Untuk mengatasi permasalahan itulah radio operator pada Kepanduan PT. Pelabuhan Indonesia III Tanjung Emas Semarang menggunakan sebuaha sarana pendukung dalam membantu meminimalisir terjadinya kesalahanpahaman yang disebabkan oleh gangguan komunikasi. Adalah kode phonetic alphabet yang berfungsi untuk mengatasi kegagalan penyampaian maksud dalam proses pertukaran informasi dalam sebuah komunikasi. Seperti yang disampaikan tim penyusun semboyan untuk mualim pelayaran besar, phonetic alphabet merupakan suatu istilah kode isyarat baku yang menggunakan huruf abjad atau alfabet sebagai penyampaian bahasa yang agaknya susah dimengerti serta lebih efektif saat disampaikan komunikator kepada komunikan (Tim Penyusun Semboyan Untuk Mualim Pelayaran Besar, 1979: 39).

Kode phonetic alphabet merupakan sarana pendukung utama dalam komuikasi pelayaran yang digunakan untuk mengeja kata ataupun kalimat secara huruf per huruf ketika terdapat informasi yang sekiranya terjadi kesalah pahaman dan tidak jelas saat disampaikan atau diterima dalam berkomunikasi radio. Kode phonetic alphabet adalah sebuah bentuk dari interaksionisme simbolik berupa kode yang digunakan dan telahdisepakati oleh pihak atau kelompok terntentu seperti yang disampaikan oleh Basrowi dan Sukidin. "Interaksi yang dilakukan antar individu itu berlangsung secara sadar dan berkaitan dengan gerak tubuh, vokal, suara, dan ekspresi tubuh, yang kesemuanya itu memopunyai maksud dan disebut dengan simbol" (Basrowi \& Sukidin dalam Engkus Suwarno, 2008: 22). Berikut adalah susunan dari kode phonetic alphabet (Alpha), B (Bravo), $C$ (Charlie), D ( Delta), $E$ (Echo), $\quad F$ (Foxtrot), $G$ (Golf), $H$ (Hotel), I (India), J (Juliet), K (Kilo), $L$ (Lima), $M$ ( Mike), $N$ (November), $O$ (Oscar), $P$ (Papa), $Q$ (Quebec), $R$ (Romeo), $S$ (Sierra), $T$ (Tango), $U$ (Uniform), $V$ (Victor), $W$ (Whiskey), $X$ (X-Ray), Y (Yankee), Z (Zulu) (Sumber: Semboyan Untuk Mualim Pelayaran Besar) Oleh radio operator PT. Pelabuhan Indonesia III Tanjung Emas Semarang. dode tersebut digunakan biasanya saat terjadi gangguan dalam komunikasi yang 
menyebabkan terjadinya penerimaan pesan yang tidak jelas sehingga timbul kesalahpahaman dalam berkomunikasi. Seperti halnya ketika terjadi cuaca buruk ataupun jarak kapal penyampai informasi masih terlalu jauh dari stasiun kepanduan, bisa dipastikan pesan menjadi tidak jelas saat kami terima, 'ataupun ketika terjadi komunikai yang melibatkan perbedaan budaya khususnya saat melakukan kontak komunikasi kepada pihak kapal berkewarganegaraan China, Vietnam, Thailand dan Korea.

Digunakan oleh warga berkewarganegaraan asing dalam menginformasikan kode call sign kapal kepada stasiun pandu berupa kode HS21 yang tidak mungkin akan diucapkan huruf abjad begitu saja karena dipastikan tidak akan bisa diterima maksud dari penyampai oleh stasiun pandu karena pelafalan huruf abjad penyampai berbeda dan harus dengan bahasa universal pada komunikasi pelayaran. Terjadi kecelakaan kapal akibat terjadi cuaca yang buruk dimana radio sebagai alat komunikasi dari kapal tidak dapat berfungsi dengan baik, kami sebagai operator stasiun kepanduan akan menyampaikan segala informasi dengan menggunakan kode phonetic alphabet untuk memaksimalkan terjadinya komunikasi yang efektif.

Kode phonetic alphabet juga berfungsi sebagai sarana pendukung bagi para pengguna komunikasi radio yang tidak fasih dalam berkomunikasi dengan menggunakan bahasa inggris, sedangkan bahasa inggris sendiri merupakan bahasa baku yang ditetapkan sebagai bahasa universal yang digunakan dalam pelayaran dunia. Sebagai penyampai atau penerima informasi yang sama-sama tidak fasih berbahsa inggris, kedua belah pihak bisa memakai kode phonetic alphabet sebagai saran apenyambung komunikasi agar tidak terjadi kesalahpahaman".

Dengan pemanfaatan dan penggunaan kode phonetic alphabet, diharapkan akan terrwujud sebuah proses komunikasi yang efektif karena tersampaikannya pesan dari komunikator kepada komunikan dan terjadi kesamaan maksud serta kesapahaman atas pesan tersebut. Dari tercapainya tujuan tersebut dipastikan muncul dampak positif serta manfaat yang besar dalam segala aspek khususnya dalam pekerjaan radio operator yang menggunakan komunikasi radio marine. Seperti yang disampaikan oleh Marhaeni Fajar bahwa tanggapan komunikan apabila tersampaikan atau disampaikan kepada komunikator terhadap isi pesan, yang dapat menimbulkan reaksi dari kedua belah pihak (Marhaeni Fajar, 2009: 59).

Komunikasi yang efektif dalam pekerjaannya berdampak baik pada ketepatan serta kelancaran dan keselamatan dalam proses pekerjaan pemanduan kapal dan pelayaran di wilayah pelabuhan. Dengan dampaik baik tersebut terjadilah kinerja yang baik dan muncul kepuasan dari para pengguna jasa yang berdampak pada

kemajuan dan bertambahnya kualitas dari PT. Pelabuhan Indonesia III Tanjung Emas Semarang beserta jajarannya, khususnya bagi radio operator stasiun kepanduan dan pihak terkait dalam pekerjaannya.

\section{PENUTUP}

\section{Kesimpulan}

Kode phonetic alphabet merupakan salah satu cara yang digunakan dalam mengatasi kegagalan penyampaian maksud dalam proses pertukaran informasi dalam sebuah komunikasi. 
Kode tersebut merupakan sarana pendukung utama dalam komunikasi radio marine yang bermanfaat untuk mengeja kata ataupun kalimat secara huruf per huruf ketika terjadi kesalahpahaman makna saat penyampaian atau penerimaan informasiyang disebabkan oleh gangguan komunikasi berupa cuaca yang buruk maupun perbedaan bahasa dan pelafalan kata karena perbedaan budaya antara kedua belah pihak.

Dengan pemahaman dan pemanfaatan kode phonetic alphabet tersebut oleh radio operator Kepanduan PT. Pelabuhan Indonesia Tanjung Emas Semarang, diharapkan dapat dimanfaatkan dalam mewujudkan sebuah komunikasi yang efektif dalam proses kerja pemanduan kapal di wilayah pelabuhan sehingga terwujudlah kelancaran dan keselamatan pelayaran.

\section{Saran}

a. Diharapkan dengan adanyapenelitian ini, para pelaku komunikasi radio marine khususnya radio operator dapat lebih memahami penggunaan serta pemanfaatan tentang kode phonetic alphabet pada komunikasi radio marine agar proses komunikasi menjadi efektif serta berdampak positif bagi kelancaran dan keselamatan pelayaran.

b. Diharapkan penelitian tentang memahami kode phonetic alphabet pada komunikasi radio marine ini dapat dilanjutkan serta diperdalam lagi pada permasalahan gangguan komunikasi radio marine dan karakteristik kode atau simbol dari phonetic alphabet oleh peneliti selanjutnya di masa mendatang.

\section{Daftar Pustaka}

Engkus Kuswarno. 2008. Etnografi Komunikasi. Bandung: Widya Padjajaran.

Kaplan, David \& Manners, Robert A. 2002. Teori Budaya (Edisi terjemahan oleh Landung Simatupang). Yogyakarta: Pustaka Pelajar.

Hatimurti Kridalaksana. 1993. Kamus Linguistik. Jakarta: Gramedia Pustaka Utama.

Lincoln, Yvonna S. \& Guba, Egon G. 1985. Naturalistic Inquiry. London New Delhi: Sage Publicatons Beverly Hills.

\& A.Foss, Karen. 2009.

Theories of communication (Edisi

9). Jakarta: Salemba Humanika.

Dedi Mulyana \&Jalaludin Rakhmat.2001.Komunikasi Antarbudaya. Bandung: PT. Remaja Rosdakarya.

Mansoer Pateda. 1988. Linguistik (Sebuah Pengantar). Bandung: Angkasa.

Marhaeni Fajar. 2009. Ilmu Komunikasi: Teori dan Praktik. Yogyakarta: Graha Ilmu.

Masri Singarimbun. 2006. Metode Penelitian Survey. Jakarta: LP3S.

H.B Sutopo. 2002. Metodologi Penelitian Kualitatif: Dasar dan Teoridan Aplikasi

Praktisnya. Surakarta: Sebelas Maret University Press.

Tim Penyusun. 1979. Semboyan Untuk Mualim Pelayaran Besar. Jakarta. http://tizna.student.fkip.uns.ac.id/2009/ 10/08/komunikasi-efektif: diunduh pada tanggal 15 april 2013 pukul 20.30 WIB.

http://www.jendelasastra.com/wawasan /artikel/hubungan-dialektologi-dansosiolinguistik-sebuah-kajianteoritis: diunduh pada tanggal 14 april 2013 pukul 15.40 WIB. 
http://komunikasi-

kumpulantugaskomunikasi.blogspot. com/2010/07/komunikasi-

lintas-budaya.html: diunduh pda tanggal 12 april 2013 pukul 19.00 WIB. http://www.pp3.co.id/ website resmi PT. Pelabuhan Indonesia III: diunduh pada tanggal 16 maret 2013 pukul 20.00 WIB. 